\title{
Effect of probiotic and asparaginate on the growth of calves and chickens
}

\author{
Olga Tyukavkina ${ }^{1,}{ }^{,}$, Stanislav Plavinsky ${ }^{1}$, Igor Tatarenko ${ }^{1}$, Lyubov Perepelkina ${ }^{1}$, and \\ Viktor Samuylo ${ }^{1}$ \\ ${ }^{1}$ The Far Eastern State Agrarian University, Blagoveshchensk, Russia
}

\begin{abstract}
The main task for the agro-industrial complex of the country and the Amur region in particular is to grow healthy livestock and obtain environmentally friendly products from it. In order to achieve these goals, special attention must be paid to the proper balanced feeding of animals, starting from the birth of the animal. In the Amur region, when harvesting their own feed, there is a shortage of normalized nutrients, which leads to a decrease in animal productivity, digestive disorders, which in turn leads to various diseases of the gastrointestinal tract and a decrease in the immune status of animals. In veterinary practice, antibiotic therapy is used to treat diseases, which along with pathogenic and conditionally pathogenic destroys useful microflora. Accumulating in the body, antibiotics cause harm not only to animals, but also carries a danger to humans. From the use of antibiotic therapy, dysbacteriosis develops, which directly affects the development of the animal as a whole. Application of probiotics to calves from the first days of life promotes early scar formation, better absorption of nutrients, which in turn leads to intensive growth and development of the young animal body. When using probiotics in animals, the intestinal microflora is normalized, thereby reducing the risk of dysbacteriosis and diarrhea, thereby improving growth, development and metabolic processes. In farms of the Amur region, the use of probiotics in feeding calves of the dairy period has not been sufficiently studied.
\end{abstract}

\section{Introduction}

Throughout the world, an important role in the development of animal husbandry is played by optimizing the feeding of farm animals, taking into account modern rationing of feeding and regional climatic and economic characteristics.

The Amur region belongs to areas with high production of its own feed. Due to sufficiently favorable climatic conditions, many agricultural plants are cultivated on its territory, many of which are used not only for human nutrition, but also for animals.

Domestic and foreign experience suggests that a significant role in the development of livestock and poultry plays them full feeding, which must be based on scientifically based system of feed production, recipes are tailored to the biological characteristics of birds, climatic and economic condition of different regions of the country

\footnotetext{
${ }^{*}$ Corresponding author: korol2702@mail.ru
} 
Currently, enzyme preparations are of particular importance in feeding young cattle and chickens. By providing stable feed quality with enzymes, the productivity of livestock production increases.

In the conditions of the South of the far Eastern region, where the basis of compound feeds is made up of feed of their own production, there is a shortage of nutrients required for poultry. Among the deficient substances, first of all, you can name protein, vitamins, and a number of macro-and microelements.

Macro-and microelements are essential components among the factors that determine the fullness of poultry feeding. Minerals have a positive effect on the metabolism of the body, only when they arrive in certain quantities in a certain ratio between themselves and other nutrients in the diet. Unlike other animals, the bird occupies a special position in terms of mineral needs.

The purpose of the research was to provide a scientific and practical justification for the use of particularly scarce trace elements Co, I, Se separately and in combination in the enzymatic probiotic "Vitacell"on the growth and metabolism of young cattle and chickens in the Amur region.

To achieve this goal, the following tasks were solved:

- in scientific and economic experience to establish the action of Co, I, Se in mineral and organic form on the growth indicators of young cattle;

- in scientific and economic experience to establish the effect of Co, I, Se in mineral and organic form on the growth rates of young chickens in different age periods;

- to study the effect of soy protein asparaginates I, Co and Se separately and in combination with the enzymatic probiotic "Vitacell" on the dynamics of live weight.

\section{Materials and Methods}

Research in the first scientific and economic experience was carried out in the conditions of LLC "Priamurye" of the Amur region on calves of the dairy period of the black-and-white breed. We formed three groups of animals with ten heads in each, selected on the principle of pairs-analogues. Calves from the control group were fed a diet adopted on the farm, the first experimental group was given soy protein asparaginates I, Co, Se in the main diet, and from the second experimental group - a complex consisting of soy protein asparaginates I, Co, Se and probiotic "Vitacell" $10 \mathrm{~g}$ each per head per day.

The second scientific and economic experiment was conducted in the conditions of JSC belogorskaya poultry farm in the Belogorsky district of the Amur region. At the beginning of the scientific and economic experiment with a duration of 119 days, the chickens were at the age of one week. Four groups were formed: a control group and three experimental groups. To conduct the experiment in the conditions of a poultry farm, young chickens of the DeKalb White cross were selected on the principle of pairs of analogues in the amount of 200 heads, from which four groups of 50 heads were formed in each.

In the scientific and economic experiment, the control group of young chickens received standard complete feed table 4. Chickens from the first experimental group were fed the same feed with the inclusion of asparaginates I, Co, Se instead of salts of the same trace elements contained in the standard feed. Chickens in the second experimental group were included in the SC $0.1 \%$ of the dry matter (SV) enzymatic probiotic. Chickens from the third experimental group included soy protein asparaginates (iodine, cobalt, and selenium) instead of mineral salts of these trace elements in combination with the probiotic "Vitacell". 


\section{Results}

As a result of the conducted scientific and economic experience, it was found that the inclusion of a complex consisting of soy protein asparaginates I, Co, Se and the probiotic "Vitacell" in the diet of calves increased the indicators of live weight and absolute growth in both experimental groups. (table 1).

Table 1. Change in live weight of calves, $(\mathrm{M} \pm \mathrm{m})$.

\begin{tabular}{|l|c|c|c|}
\hline \multirow{2}{*}{\multicolumn{1}{|c|}{ Indicator }} & \multicolumn{3}{c|}{ Group } \\
\cline { 2 - 4 } & \multirow{2}{*}{ Control } & 1 & 2 \\
\cline { 3 - 4 } & $44.4 \pm 1.08$ & $44.1 \pm 1.25$ & $44.8 \pm 1.13$ \\
\hline $\begin{array}{l}\text { Live weight at the beginning of the } \\
\text { experiment, } \mathrm{kg}\end{array}$ & $143.4 \pm 1.06$ & $152.6 \pm 1.44$ & $155.3 \pm 1.29$ \\
\hline $\begin{array}{l}\text { Live weight at the end of the } \\
\text { experiment, } \mathrm{kg}\end{array}$ & 99.0 & 107.8 & 111.2 \\
\hline Absolute gain, kg & 550.0 & 599.0 & 617.8 \\
\hline Average daily growth, $\mathrm{g}$ & 100 & 108.9 & 112.3 \\
\hline In\% of the control group & &
\end{tabular}

As can be seen from the table data, at the beginning of the experiment, the average weight of calves did not differ. At the end of the experiment, calves from the second experimental group, who were fed a complex of enzymatic probiotics, had better indicators. Fig. 1 shows the average daily growth rate.

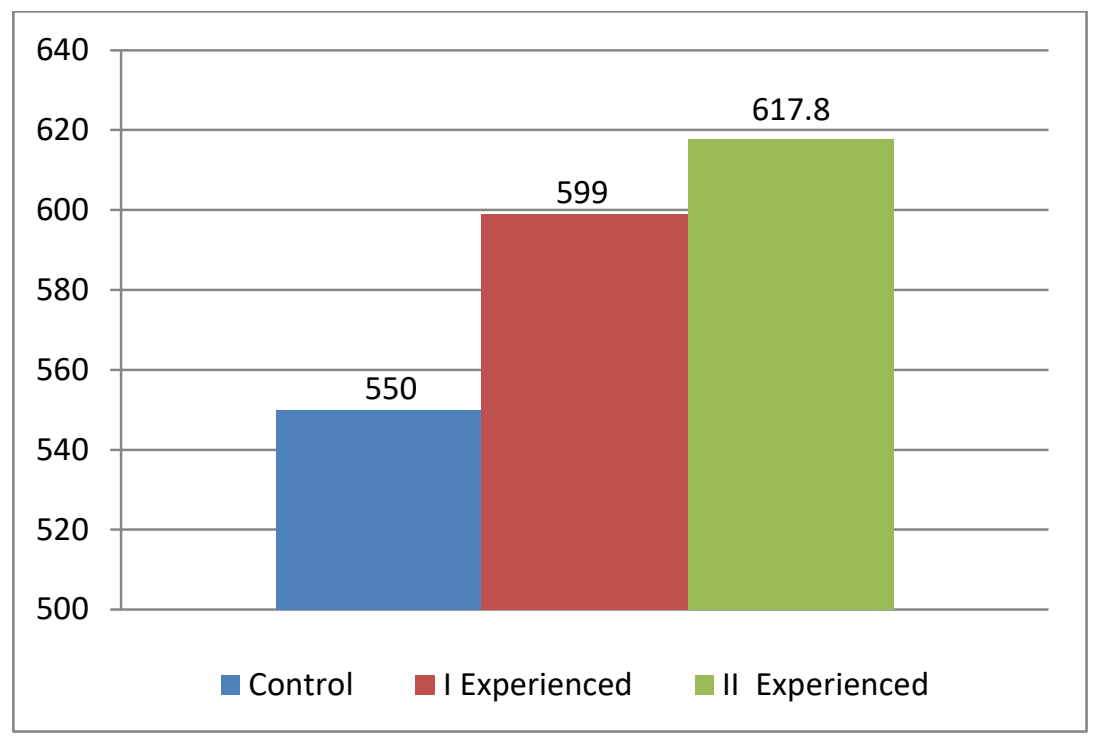

Fig. 1. Average Daily growth of calves, g.

So, the best performance was in the second experimental group and amounted to 617,8 $\mathrm{g}$, which was $67.8 \mathrm{~g}$ more than those in the control group and first experimental group these figures were also higher than in the control and amounted to $599 \mathrm{~g}$. The absolute increase was highest in the second experimental group $-111.2 \mathrm{~kg}$, and in the first experimental group it was $107.8 \mathrm{~kg}$.

At the end of the scientific and economic experiment, a physiological (balance) experiment was conducted on calves at the age of six months. By studying the amount of 
nutrients consumed and excreted with feces, we determined the digestibility coefficients of raw protein, raw fat, raw fiber, and nitrogen-free extractives (BAS)

Figure 1 shows that the digestibility coefficients of raw protein were higher in the experimental groups compared to the control groups.

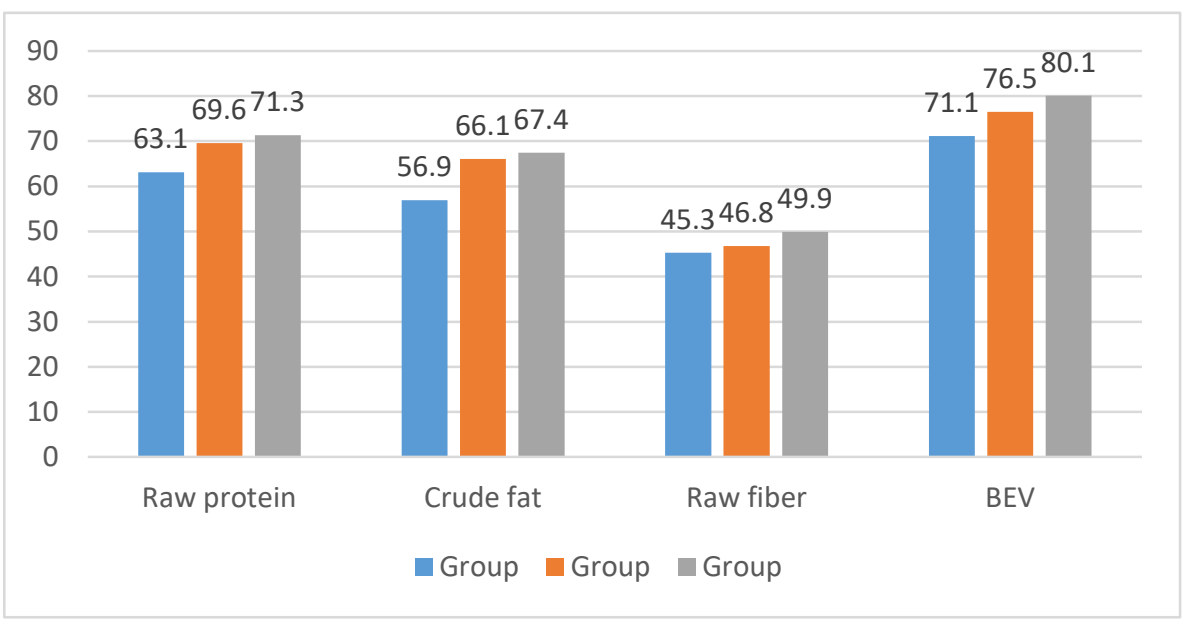

Fig. 2. Digestibility of nutrients, \%.

During the physiological experiment, it was found that calves from both experimental groups digested all the normalized organic substances better than the control group. Protein digestibility was the best in the second experimental group and amounted to $71.3 \%$, in the first $-69.6 \%$, and $63.1 \%$ - in the control group. A similar pattern was observed for fat digestibility. Thus, the fat digestibility coefficient for calves of the second group was $67.4 \%$, slightly lower in the first group and the lowest in the control group was $56.9 \%$.

When determining the balance of nitrogen, calcium and phosphorus, it was found that it was positive in all experimental calves (Fig. 3)

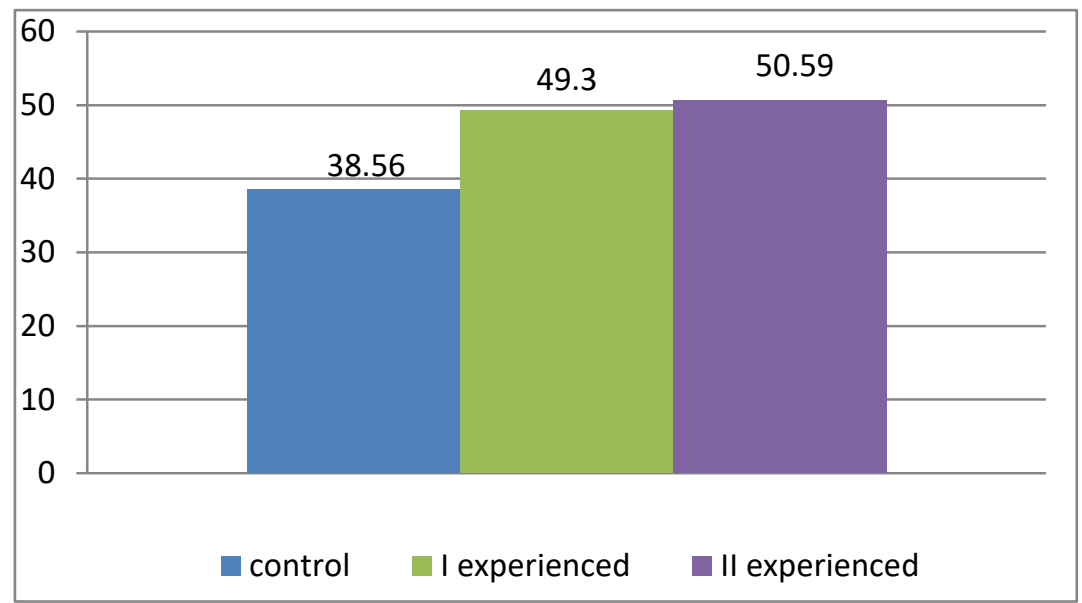

Fig. 3. Nitrogen absorption Coefficient, $\%$.

The coefficient of nitrogen use from the taken was the highest in calves of the second experimental group and amounted to $50.49 \%$, it was slightly less in the first experimental group. It was the lowest in the control group. 


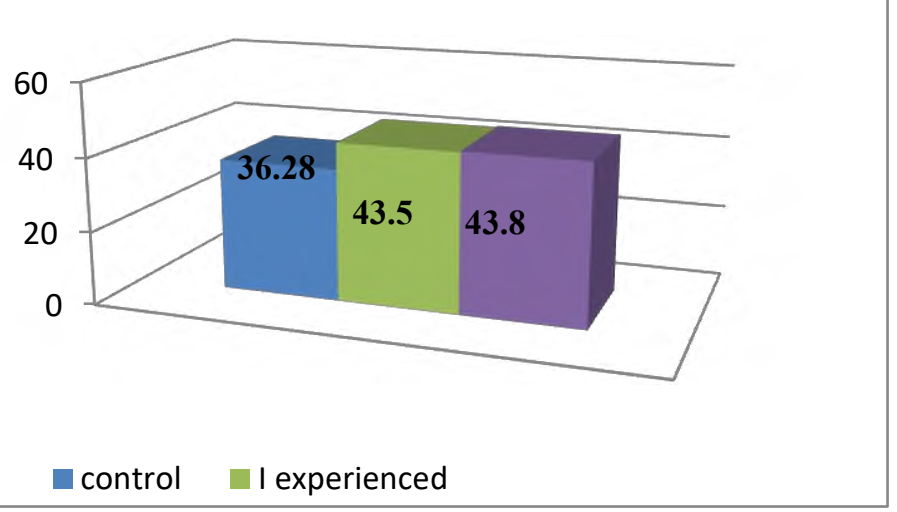

Fig. 4. Calcium utilization Rate, $\%$.

The most optimal balance of calcium and phosphorus was when feeding calves a complex consisting of soy protein asparaginates I, Co, Se and the probiotic "Vitacell" . Such feeding conditions were in the second experimental group compared to the control group.

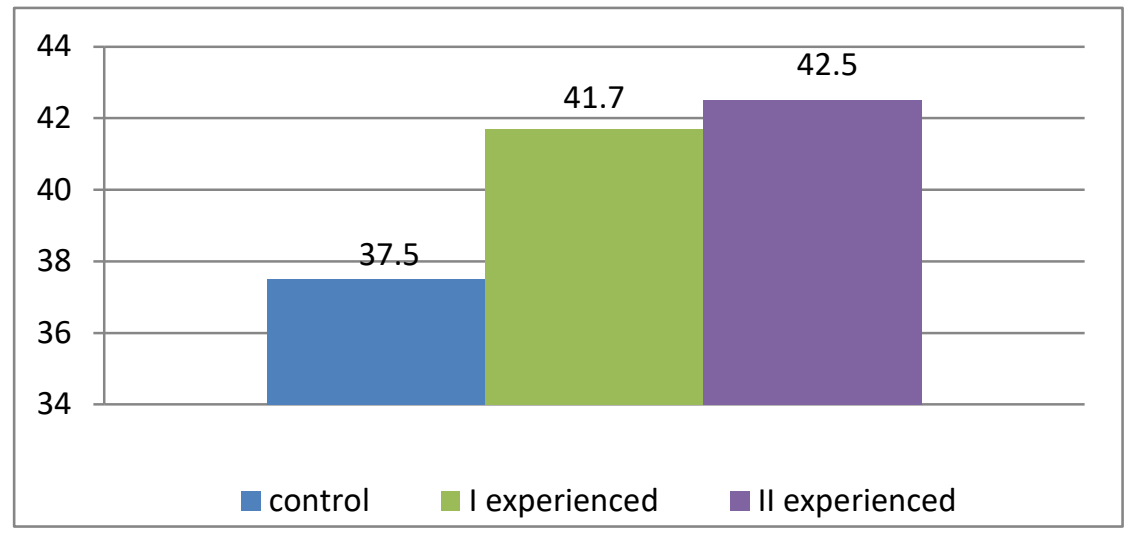

Fig. 5. Phosphorus utilization rate, $\%$.

Thus, in the physiological (balance) experiment, a positive effect of feeding a complex consisting of soy protein asparaginates I, Co, Se and the probiotic "Vitacell" on metabolic processes was established.

Morphological and biochemical parameters of blood were also studied. The data is presented in table 2 .

Table 2. Morphological and biochemical parameters, $(\mathrm{M} \pm \mathrm{m})$.

\begin{tabular}{|c|c|c|c|c|}
\hline \multirow{2}{*}{ Indicator } & \multirow{2}{*}{ Norm } & \multirow{3}{|c|}{ Group } \\
\cline { 4 - 5 } & & \multirow{2}{*}{ Control } & \multicolumn{2}{|c|}{ Experienced } \\
\cline { 4 - 5 } & & & 1 & 2 \\
\hline Hemoglobin, g/1 & $90-120$ & $91.4 \pm 1.51$ & $114.8 \pm 1.58$ & $115.1 \pm 1.64^{* *}$ \\
\hline White blood cells, $10^{9} / 1$ & $12.0-16.0$ & $14.0 \pm 0.24$ & $14.3 \pm 0.35$ & $14.3 \pm 0.22$ \\
\hline Red blood cells, $10^{12} / 1$ & $5.05-7.5$ & $5.3 \pm 0.12$ & $7.2 \pm 0.17$ & $7.4 \pm 0.25$ \\
\hline Total protein, g/1 & $75.0-85.0$ & $74.2 \pm 1.22$ & $80.1 \pm 1.34$ & $84.3 \pm 1.46$ \\
\hline
\end{tabular}

Analyzing the table data, it can be seen that the main blood parameters in calves from the control group were at the lower limit of the physiological norm, while in calves from the experimental groups, these indicators were average in relation to the norm. 
As a result of the second scientific and economic experiment, it was found that the feeding of compound feed with the inclusion of asparaginates I, Co, Se and the enzymatic probiotic "Vitacell" in different quantities had a different effect on the dynamics of live weight.

For chickens aged from one to seven weeks, the highest indicators for live weight were in the second experimental group when the compound feed included $+0.1 \%$ of the total feed CONTENT of the enzymatic probiotic "Vitacell".

It was found that the average daily growth in young chickens from the experimental groups was significantly higher compared to the control group.

Table 3. Change in live weight of young chickens in the first age period, $(\mathrm{M} \pm \mathrm{m})$.

\begin{tabular}{|c|c|c|c|c|}
\hline \multirow{2}{*}{ Indicators } & \multicolumn{4}{|c|}{ Group } \\
\cline { 2 - 5 } & control & \multicolumn{4}{|c|}{ I experienced } & \multicolumn{2}{|c|}{ II experienced } & III experienced \\
\cline { 2 - 5 } & 2 & \multicolumn{4}{|c|}{ Age from 1 to 7 weeks (PC-2) } \\
\hline 1 & 3 & 4 & 5 \\
\hline $\begin{array}{c}\text { Live weight at the } \\
\text { beginning of the } \\
\text { experiment, }\end{array}$ & $93.7 \pm 3.31$ & $93.9 \pm 1.41$ & $94.7 \pm 1.52$ & $95.5 \pm 1.61$ \\
\hline $\begin{array}{c}\text { Live weight at the } \\
\text { end of the } \\
\text { experiment, } g\end{array}$ & $440.4 \pm 2.31$ & $451.2 \pm 2.56$ & $452.8 \pm 2.63$ & $457.5 \pm 2.77$ \\
\hline Absolute growth, g & 347.6 & 357.9 & 358.4 & 362.7 \\
\hline $\begin{array}{c}\text { Average daily } \\
\text { growth, g }\end{array}$ & 8.2 & 8.6 & 8.6 & 8.8 \\
\hline $\begin{array}{c}\text { In \% of the control } \\
\text { group }\end{array}$ & 100 & 102.8 & 103.3 & 104.8 \\
\hline
\end{tabular}

The live weight of one head at the end of the experiment was $457.5 \mathrm{~g}$, i.e. 17.1 grams more than in the control group. In the other experimental groups, the average daily increase increased by $2.2-2.8 \%$ relative to the control group.

Thus, the best results on the live weight of young chickens were observed in the second age period when they were fed PC-3 compound feed with the inclusion of asparaginates I, Co, Se and the enzymatic probiotic "Vitacell" in its composition (table 3).

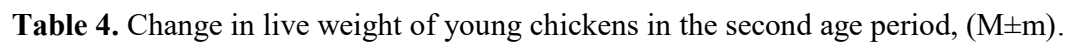

\begin{tabular}{|l|c|c|c|c|}
\hline \multirow{2}{*}{ Indicators } & \multicolumn{4}{|c|}{ Group } \\
\cline { 2 - 5 } & control & \multicolumn{4}{|c|}{ I experienced } & II experienced & III experienced \\
\cline { 2 - 5 } $\begin{array}{l}\text { Live weight at the } \\
\text { beginning of the } \\
\text { experiment, }\end{array}$ & $440.6 \pm 2.31$ & $451.3 \pm 2,56$ & $452.2 \pm 2.63$ & 458.412 .77 \\
\hline $\begin{array}{l}\text { Live weight at the } \\
\text { end of the } \\
\text { experiment, g }\end{array}$ & $804.5 \pm 5.54$ & $820.6 \pm 5.35^{*}$ & $828.2 \pm 5.22$ & $845.8 \pm 5.28^{* * *}$ \\
\hline Absolute growth, g & 361.4 & 369.6 & 375.6 & 388.3 \\
\hline $\begin{array}{l}\text { Average daily } \\
\text { growth, g }\end{array}$ & 8.64 & 8.87 & 8.94 & 9.22 \\
\hline $\begin{array}{l}\text { In \% of the control } \\
\text { group }\end{array}$ & 100 & 102.6 & 104.3 & 107.5 \\
\hline
\end{tabular}

The live weight at the end of the experiment in the third experimental group was 845.8 g, i.e. $41.3 \mathrm{~g}$ more than in the control group. In all other experimental groups, this difference was on average $26.6 \mathrm{~g}$. the Absolute increase in the third experimental group was 
$388.3 \mathrm{~g}$, in the control group-361.4 g, which is $7.4 \%$ more. In all other experimental groups, the chickens outperformed the control ones by $2.4-6.6 \%$.

Table 5. Change in live weight of young chickens in the third age period, $(M \pm t)$.

\begin{tabular}{|l|c|c|c|c|}
\hline \multirow{2}{*}{ Indicators } & \multicolumn{4}{|c|}{ Group } \\
\cline { 2 - 5 } & control & I experienced & II experienced & $\begin{array}{c}\text { III } \\
\text { experienced }\end{array}$ \\
\hline \multicolumn{4}{|c|}{ Age from 14 to 17 weeks (PC-4) } \\
\hline $\begin{array}{l}\text { Live weight at the } \\
\text { beginning of the } \\
\text { experiment, g }\end{array}$ & $801.6 \pm 5.54$ & $820.4 \pm 5.35$ & $828.2 \pm 5.22$ & $845.7 \pm 5.28$ \\
\hline $\begin{array}{l}\text { Live weight at the } \\
\text { end of the } \\
\text { experiment, g }\end{array}$ & $992.3 \pm 6.97$ & $1015.8 \pm 6.96$ & $1022.3 \pm 7.02$ & $1042.7 \pm 7.05$ \\
\hline Absolute growth, g & 190.8 & 195.3 & 193.6 & 197.2 \\
\hline $\begin{array}{l}\text { Average daily } \\
\text { growth, g }\end{array}$ & 6.7 & 6.8 & 6.8 & 7.2 \\
\hline $\begin{array}{l}\text { In \% of the control } \\
\text { group }\end{array}$ & 100 & 102.4 & 101.6 & 103.4 \\
\hline
\end{tabular}

From the data shown in table 6, it can be seen that for young chickens aged from 13 to 17 weeks, higher indicators compared to the control and other experimental groups for growth were in young chickens when they were fed PC-4 asparaginates I, Co, Se and the enzymatic probiotic "Vitacell".

The live weight at the end of the experiment in the third experimental group was 1042.7 g, i.e. $50.3 \mathrm{~g}$ more than in the control group. In all other experimental groups, this difference was from 20.4 to $38.3 \mathrm{~g}$. the Absolute increase in the third experimental group was $197.2 \mathrm{~g}$, in the control group-190.8 $\mathrm{g}$, which is $6.4 \mathrm{~g}$ more. The average daily increase was also higher in the third experimental group-7.2 $\mathrm{g}$ compared to $6.7 \mathrm{~g}$ in the control group.

When studying linear growth, the advantage remained for the third experimental group, where asparaginates I, Co, Se and the enzymatic probiotic "Vitacell" were introduced into the PC-4 (table 6).

Table 6. Main measurements of young chickens at the age of 17 weeks, $\mathrm{mm}$.

\begin{tabular}{|l|c|c|c|c|}
\hline \multirow{2}{*}{ Measurements } & \multicolumn{4}{|c|}{ Groups } \\
\cline { 2 - 5 } & control & I experienced & II experienced & III experienced \\
\hline Body length & $151.4 \pm 1.62$ & $156.3 \pm 1.19$ & $158.5 \pm 1.81$ & $165.2 \pm 3.15$ \\
\hline $\begin{array}{l}\text { Chest } \\
\text { circumference }\end{array}$ & $260.6 \pm 2.72$ & $2760.3 \pm 1.09$ & $277.4 \pm 4.59$ & $289.4 \pm 6.26$ \\
\hline The depth of chest & $98.7 \pm 0.11$ & $99.3 \pm 0.06$ & $97.5 \pm 0.33$ & $98.3 \pm 0.08$ \\
\hline Chest width & $64.2 \pm 0.13$ & $64.5 \pm 0.19$ & $65.2 \pm 0.37$ & $66.3 \pm 0.62$ \\
\hline $\begin{array}{l}\text { The length of the } \\
\text { keel }\end{array}$ & $80.6 \pm 0.04$ & $80.6 \pm 0.03$ & $80.2 \pm 0.21$ & $80.7 \pm 0.13$ \\
\hline $\begin{array}{l}\text { The width of the } \\
\text { pelvis }\end{array}$ & $90.4 \pm 1.16$ & $94.3 \pm 0.27$ & $97.3 \pm 2.19$ & $102.5 \pm 2.64$ \\
\hline Hip length & $80.3 \pm 0.21$ & $80.8 \pm 0.19$ & $81.4 \pm 0.24$ & $82.3 \pm 0.72$ \\
\hline Shin length & $108.3 \pm 1.26$ & $112.6 \pm 0.68$ & $112.8 \pm 0.95$ & $118.7 \pm 2.90$ \\
\hline $\begin{array}{l}\text { The length of the } \\
\text { shank }\end{array}$ & $69.3 \pm 1.02$ & $72.4 \pm 0.40$ & $74.6 \pm 1.25$ & $78.3 \pm 2.63$ \\
\hline
\end{tabular}


At the age of 17 weeks, the chickens from the third experimental group had a trunk length of $165.2 \mathrm{~mm}$, a keel of $80.7 \mathrm{~mm}$, and the chickens from the control group had these indicators, respectively: $-151.4 \mathrm{~mm}$ and $80.6 \mathrm{~mm}$. The same was observed for the height of examples such as chest circumference, chest depth, chest width, pelvic width, hip length, Shin length, and metatarsal length.

The results of the experiment suggest a positive effect of asparaginates I, Co, Se and the enzymatic probiotic "Vitacell" in the diet of young chickens.

To determine the development of young chickens at the end of the scientific and economic experience, body indices were calculated table 7 .

Table 7. Indices physique of young chickens at the age of 16 weeks, $\%$.

\begin{tabular}{|l|c|c|c|c|}
\hline \multirow{2}{*}{ Indexes } & \multicolumn{4}{|c|}{ Groups } \\
\cline { 2 - 5 } & control & I experienced & II experienced & III experienced \\
\hline Breadth index & 59.5 & 60.6 & 61.5 & 63.7 \\
\hline $\begin{array}{l}\text { The index of } \\
\text { compactness }\end{array}$ & 172.5 & 173.4 & 174.4 & 175.9 \\
\hline Thoracic I index & 64.6 & 65.2 & 66.5 & 68.3 \\
\hline Chest index II & 79.6 & 80.8 & 81.3 & 82.6 \\
\hline High-legged index & 45.3 & 46.1 & 46.5 & 47.6 \\
\hline
\end{tabular}

From the data shown in table 7 , it can be seen that for young chickens, the best body indices are observed in the third experimental group.

The question of optimal supply of poultry needs in nutrients can not be solved only in scientific and economic experience. In this regard, we conducted balance experiments to determine the degree of assimilation of certain organic substances. During the period of scientific and economic experience conducted on young chickens in three age periods, the balance experiment was conducted at the age of 16 weeks (table 8).

Table 8. Digestibility of nutrients, $\%$.

\begin{tabular}{|l|c|c|c|c|}
\hline \multirow{2}{*}{ Indicator } & \multicolumn{4}{|c|}{ Groups } \\
\cline { 2 - 5 } & control & I experienced & II experienced & III experienced \\
\hline Crude protein & $67.7 \pm 1.15$ & $71.6 \pm 1.83$ & $72.8 \pm 2.05$. & $73.8 \pm 2.11$ \\
\hline Crude fat & $62.3 \pm 1.25$ & $63.3 \pm 1.43$ & $65.2 \pm 1.55$ & $70.5 \pm 1.63$. \\
\hline Raw fiber & $10.5 \pm 0.22$ & $10.7 \pm 0.28$ & $10.8 \pm 0.29$ & $11.3 \pm 0.31^{*}$ \\
\hline BEV & $73.7 \pm 0.27$ & $74.8 \pm 1.12$ & $75.7 \pm 1.31$ & $76.4 \pm 1.29^{*}$ \\
\hline
\end{tabular}

The conducted balance experiment on the study of the digestibility of normalized organic substances by young chickens confirmed the results obtained in scientific and economic experiments on changes in live weight. Thus, the highest digestibility coefficients of protein and fat were in chickens that were fed asparagates I, Co, Se and the enzymatic probiotic "Vitacell"in the compound feed.

As a result of physiological experience, it was found that feeding asparaginates I, Co, Se and the enzymatic probiotic "Vitacell". the composition of compound feeds has a positive effect on the digestibility and assimilation of nutrients in the diet.

When studying the nitrogen balance, it was found that the nitrogen absorption coefficients were the highest when feeding mixed feed with the inclusion of asparaginates I, Co, Se and the enzymatic probiotic "Vitacell" (table 8). the Best indicator for the nitrogen absorption coefficient was in the third experimental group and amounted to $73.8 \%$, which is $6.1 \%$ more than the control group.

In the diets of chickens, the concentration of calcium and phosphorus corresponded to the standards given in the manual for the maintenance of industrial herd cross DeKalb White. The absorption and balance of calcium and phosphorus were analyzed 
by the subjects depending on the level of asparaginates I, Co, Se and $0.1 \%$ of the probiotic "Vitacell" in the diet (table 10-11).

Table 9. Nitrogen Balance.

\begin{tabular}{|c|c|c|c|c|}
\hline \multirow{2}{*}{ Indicator } & \multicolumn{4}{|c|}{ Groups } \\
\cline { 2 - 5 } & control & I experienced & II experienced & III experienced \\
\hline Taken with food, g & $2.07 \pm 0.02$ & $2.07 \pm 0.02$ & $2.07 \pm 0.01$ & $2.07 \pm 0.03$ \\
\hline $\begin{array}{c}\text { Selected with a } \\
\text { mark, g }\end{array}$ & $0.66 \pm 0.02$ & $0.62 \pm 0.01$ & $0.55 \pm 0.03$ & $0.57 \pm 0.03$ \\
\hline Learned, g & $1.43 \pm 0.02$ & $1.48 \pm 0.02$ & $1.54 \pm 0.03$ & $1.56 \pm 0.02$ \\
\hline $\begin{array}{c}\text { Coefficient of } \\
\text { assimilation, \% }\end{array}$ & 67.7 & 71.4 & 72.6 & 73.8 \\
\hline
\end{tabular}

Table 10. Calcium Balance.

\begin{tabular}{|l|c|c|c|c|}
\hline \multicolumn{1}{|c|}{ Group } & Taken by feed, $\mathrm{g}$ & $\begin{array}{c}\text { Selected with a } \\
\text { mark, } \mathrm{g}\end{array}$ & Learned, g & $\begin{array}{c}\text { Coefficient of } \\
\text { assimilation, \% }\end{array}$ \\
\hline control panel & $2.50 \pm 0.17$ & $1.47 \pm 0.02$ & $1.03 \pm 0.02$ & 41.3 \\
\hline I experienced & $2.50 \pm 0.11$ & $1.46 \pm 0.04$ & $1.04 \pm 0.03$ & 41.8 \\
\hline II experienced & $2.50 \pm 0.17$ & $1.40 \pm 0.03$ & $1.10 \pm 0.05$ & 44.2 \\
\hline III experienced & $2.50 \pm 0.07$ & $1.36 \pm 0.05$ & $1.14 \pm 0.04$ & 45.3 \\
\hline
\end{tabular}

Table 11. Phosphorus Balance.

\begin{tabular}{|c|c|c|c|c|}
\hline Group & $\begin{array}{c}\text { Taken by } \\
\text { feed, } g\end{array}$ & $\begin{array}{c}\text { Selected with a } \\
\text { mark, } g\end{array}$ & Learned, g & $\begin{array}{c}\text { Coefficient of } \\
\text { assimilation, \% }\end{array}$ \\
\hline control panel & $0.70 \pm 0.01$ & $0.43 \pm 0.01$ & $0.27 \pm 0.01$ & 38.5 \\
\hline I experienced & $0.70 \pm 0.02$ & $0.38 \pm 0.02$ & $0.32 \pm 0.02$ & 45.3 \\
\hline II experienced & $0.70 \pm 0.03$ & $0.39 \pm 0.01$ & $0.31 \pm 0.02$ & 44.6 \\
\hline III experienced & $0.70 \pm 0.03$ & $0.36 \pm 0.02$ & $0.34 \pm 0.02$ & 48.8 \\
\hline
\end{tabular}

From the data in table 10, it can be seen that the absorption of calcium by chickens that received asparagates $\mathrm{I}, \mathrm{Co}$, Se and the enzymatic probiotic "Vitacell" in the diet as part of compound feeds was the highest. At the same time, the coefficient of calcium absorption in control chickens was $41.3 \%$. The highest coefficient of calcium absorption was observed in the third experimental group- $45.3 \%$ and was higher than the control group by $4 \%$. Phosphorus uptake by young chickens of the third experimental group was also the best and amounted to $48.8 \%$.

Thus, based on the results of physiological experience, it was found that the introduction of asparaginates I, Co, Se and the enzymatic probiotic "Vitacell" in the composition of compound feeds had a positive effect on the digestibility and assimilation of nutrients in the diet, which indicates the optimization of mineral metabolism.

\section{Discussion}

To date, the positive effect of probiotics has been proven, while it has been established that the use of a complex probiotic drug based on strains of bacteria of the genus Bacillus prevents the occurrence of diseases of the gastrointestinal tract, promotes protein metabolism, and does not have a toxic effect on the liver and kidneys. In addition to preventive and therapeutic purposes, probiotic drugs are used to improve the reproductive qualities of animals, stimulate the growth and development of young animals, and obtain additional gains in live weight. Probiotic preparations containing live cultures of microorganisms-symbionts of the gastrointestinal tract are harmless and do not have the disadvantages inherent in antibiotics and chemotherapeutic agents [1]. 
Thus, the use of various feed additives, using probiotics, have a favorable effect on the metabolism, digestive processes and the use of nutrients at a high level, which allows you to accelerate the growth and development of animals and increase their productivity.

In the conditions of the Amur region, where the rations use feed of their own production, there is a shortage of normalized nutrients for animals.

Currently, there is a large scientific and practical knowledge about the importance and impact of balanced feeding of farm animals. At the same time, in the issue of balanced feeding, it is impossible not to take into account the zonal features of animal husbandry.

\section{Conclusions}

1. Introduction to the diet of calves of the complex of enzymatic probiotics "Vitacell" and "Promilk" in comparison with calves from the control group, their average daily increase was greater by $8.9 \%$, the digestibility of crude protein- by $6.5 \%$, crude fat - by $9.2 \%$, crude fiber - by $1.5 \%$, BEV - by $5.4 \%$, nitrogen absorption - by $10.74 \%$, calcium - by $7.22 \%$, phosphorus-by $4.2 \%$.

2. Morphological and biochemical parameters of blood in young cattle when feeding them diets with a complex of enzymatic probiotics increased the processes of hematopoiesis. The inclusion of enzymatic probiotics in the calves ' diets, without going beyond the physiological norm, increased the indicators to the upper limit of the norm, hemoglobin by $25.6-25.9 \%$, red blood cells- $35.8-39.65 \%$.

3. in a comparative study of the effect of mineral and organic forms of I, Co and Se, it was found that feeding young chickens of a dietary Supplement containing I, Co and Se in the form of soy protein asparaginates contributed to an increase in the average daily increase by $2.6 \%$ in the first age period, by $2.6 \%$ in the second and by $2.4 \%$ in the third.

4. the best indicators for live weight in chickens were when feeding a feed additive containing asparaginates $\mathrm{I}, \mathrm{Co}$ and $\mathrm{Se}$ in combination with the enzymatic probiotic "Vitacell". The average daily increase in the third age period increased by $3.4 \%$ compared to the control group.

\section{References}

1. A.V. Andreeva, D. V. Kadyrova, D. R. Samigullina, G. B. Bozova Influence of the probiotic "Vetosporin" on the hematological status of newborn calves, Scientific notes of the Bauman Kazan state Academy of veterinary medicine 211, 21-26 (2012)

2. M. N. Gagarina, L. I. Drozdova Probiotic "Bacell" and its effect on the body of calves on fattening Agrarian Bulletin of the Urals 1(93), 31-32 (2012)

3. G. I. Kotsyunbas, V. M. Lemishevsky Influence of PROBION-FORTE feed additive on morphofunctional state of pig duodenum Veterinary science. 5, 56-60 (2014)

4. K. S. Luchkin, A. Y. Rudisin, S. V. Burtseva Hematological indicators of pigs when using probiotics in their diet Bulletin of the Altai state agrarian University, 3(101), 6971 (2013)

5. I. N. Medvedev, I. A. Goryainova, M. M. Naumov, M. N. Pavlov Aggregation activity of platelets in newborn calves with dyspepsia Izvestiya Timiryazevskaya agricultural Academy 4, 172-176 (2006)

6. A. S. Moskvina Change of morphophysiological parameters of blood of calves with age and in the process of vaccination Russian veterinary journal. Farm animals. 1. 2830 (2012) 
7. R. V. Nekrasov, M. G. Chabaev, N. I. Anisova, A. S. Anikin Probiotic of the new generation in feeding cows Achievements of science and technology of the agro industrial complex 3, 38-40 (2013)

8. A. A. Ovchinnikov, L. V. Ivanova, E. V. Ivanov Changes in the intestinal microflora of calves of the dairy growing period when using a sorbent and probiotic in the diet Veterinary doctor, 1, 37-39 (2012)

9. Podvorok, N. I. Use of starter feed for growing calves up to 6 months of age , Proceedings of the INTERNATIONAL scientific and practical conference "Topical issues of animal science and practice as a basis for improving the productive qualities and health of farm animals", 131-134 (2005)

10. Popkov, N. A. Effectiveness of new whole milk substitutes enriched with domestic probiotics when feeding calves, Collection of scientific works "Zootechnical science of Belarus", 45, 169-176 (2010)

11. N. A. Pyshmantseva Scientific substantiation of practical application of domestic probiotics in poultry and animal husbandry Diss. na soisk. Uchen. step. Doctor of agricultural Sciences, Krasnodar, 350(2012)

12. E. N. Chernenkov, I. V. Mironova, A. Ya. Gizatov Influence of probiotic biohumer on hematological parameters of rabbits Izvestiya Orenburg state agrarian University, 3, 203-205 (2015)

13. K. R. Babukhadiya Influence of feeding, processed by different methods of soy grain on the productivity of laying hens autoref, 18 (2005)

14. V. TS. Nimaeva, T. A. Krasnoshchekova Feeding chromium-containing mineral additives to young chickens Feeding of farm animals and feed production, 5-6, 35-44 (2015)

15. A. S. Prostokishin, T. A. Krasnoshchekova, E. V. Tuaeva Optimization of feeding of young cattle and chickens by using non-traditional feeds and chelated compounds of normalized trace elements, 14-15 (2015) 